\title{
The investigation of calpastatin and thyroglobulin gene polymorphisms in some native cattle breeds*
}

\author{
Mustafa SAVAŞÇ $\mathbf{I}^{1}$, Fatih ATASOY ${ }^{2}$ \\ ${ }^{1}$ Ankara University, Graduate School of Healty Sciences, Ankara; ${ }^{2}$ Ankara University, Faculty of Veterinary Medicine, Deparment \\ of Animal Husbandry, Ankara. Turkey.
}

\begin{abstract}
Summary: In this study, calpastatin gene polymorphisms, known to have effect on meat tenderness, and thyroglobulin gene polymorphisms, known to affect marbling score, were investigated in some local cattle breeds raised in Turkey (Anatolian Native Black-ANT (n=36), Eastern Anatolian Red-EAR (n=51) and Turkish Grey-TG $(n=52)$. The genetic variants in the bovine CAST and $T G$ gene were analysed by using the polymerase chain reaction-restriction fragment length polymorphism (PCR-RFLP) method. It was determined that while the calpastatin gene possessed the $\mathrm{C}$ allele, known to have a positive effect on meat tenderness, at a high frequency (0.67), suggesting that the local cattle breeds presented with a high potential for high quality meat production, the thyroglobulin gene was ascertained to possess the favourable $T$ allele at a relatively low frequency ( 0.23$)$, which could be increased with marker-assisted selection. It has been ascertained that the local cattle breeds investigated, and in particular the EAR had the potential to produce high quality red meat. Genetic analyses revealed the $\mathrm{F}_{\mathrm{IS}}, \mathrm{F}_{\mathrm{It}}$ and $\mathrm{F}_{\mathrm{St}}$ values to be $-0,010,0.045$ and 0.055 , respectively. These values showed that the local cattle breeds investigated displayed a high genetic diversity. Additionally, The allelic frequencies were calculated according to the Hardy-Weinberg equilibrium, and the differences between the cattle breeds were found to be statistically significant.
\end{abstract}

Key words: Calpastatin, Meat Quality, Native cattle, PCR-RFLP, Thyroglobulin.

\section{Bazı yerli sığır ırklarında kalpastatin ve thyroglobulin gen polimorfizmlerinin araştırılması}

Özet: Türkiye'de bulunan bazı yerli sığır ırklarında (Yerli Kara-YK, n=36; Doğu Anadolu Kırmızısı-DAK (n=51) ve Boz IrkBI $(n=52)$ et kalite özelliklerinden gevrekleşme üzerine etkili kalpastatin ve mermerleşme derecesi üzerine etkili thyroglobulin gen polimorfizmleri, polimeraz zincir reaksiyonu-restriksiyon parça uzunluk polimorfizmi (PCR-RFLP) metodu kullanılarak araştırılmıştır. Kalpastatin geninde et gevrekliği üzerine olumlu etkisi olan C allelinin yüksek frekansta (0.67) bulunduğu ve yerli sığır ırklarının yüksek potansiyel taşıdığı ,thyroglobulin için ise faydalı $\mathrm{T}$ allelinin nisbi olarak düşük frekansta bulunduğu (0.23) marker destekli seleksiyonla frekansının artırılabileceği ortaya çıkmıştır. Yerli sığır ırklarının özellikle DAK'ın kaliteli kırmızı et üretimi için potansiyel taşıdığı tespit edilmiştir. Genetik analizler sonucunda $F_{I S}, F_{\text {It }}$ ve $F_{S t}$ değerleri sırasıyla $-0,010,0,045$ ve 0,055 olarak tespit edilmiştir. Bu sonuçlara göre incelenen genler bakımından yerli sığır ırklarının yüksek genetik çeşitliliğe sahip olduğu belirlenmiştir. Ayrıca allel frekansları Hardy-Weinberg denge kuralına uygun olarak hesaplanarak irklar arasında farkın önemli olduğu bulunmuştur.

Anahtar sözcükler: Kalpastatin, Et kalitesi, PCR-RFLP, Thyroglobulin, Yerli sığır ırkları.

\section{Introduction}

In the beef cattle industry, multiple genes, including calpastatin and thyroglobulin, are known to have effect on meat quality (15). It has been reported that the effect of the calpastatin gene (CAST) on meat tenderness is determined by measuring the Warner-Bratzler shear force (WBS) value. Calpastatin, which is an endogenous calpain inhibitor, plays a key role in the regulation of calpain activity in the cell, and does not inhibit proteases other than calpain. Calpastatin affects meat tenderness indirectly, by means of its effect on calpain. Calpastatin, alongside calpain, is found in the cytosol and cell membrane. Calpastatin contains four inhibitory regions, and one molecule of calpastatin inhibits four molecules of calpain (5). It has been reported that CAST indirectly enables the post-mortem breakdown of the myofibrillar proteins, through its involvement in the regulation of the activity of calpain, which leads to the proteolysis of the myofibrils (12). A G/C polymorphism at the $29,602^{\text {nd }}$ nucleotide has effect on meat tenderness (14).

The thyroglobulin gene $(T G)$ encodes the thyroglobulin protein, which acts as the precursor of triiodothyronine and tetraiodothyronine and is involved in the development of adipocytes (2). For a long time, it

\footnotetext{
This work is a summary of PhD thesis having the some title.
} 
has been known that thyroid hormones are involved in the deposition of fat between myocytes. It has been suggested that, in cattle, a polymorphisim detected in the 5 UTR- untranslated region of the $T G$ gene alters the transcriptional and translational activities of the gene (7). In cattle, this polymorphism has been demonstrated to affect the marbling score, a meat quality characteristic. However, until the publication of the research conducted by Barendse et al. (4) marbling and polymorphism were not known to be associated to each other. Reports indicate that these polymorphisms could be utilized in the selection of animals for their marbling traits, and thus, for the production of meat as demanded by the market. However, it should be taken into consideration that, of the meat quality characteristics, the marbling score is affected by multiple genes, and therefore, under suboptimal environmental conditions, even cattle with favourable alleles may not produce meat with a high marbling score (8).

This study was aimed at the determination of the calpastatin and thyroglobulin gene polymorphisms, known to affect meat quality, in some local cattle breeds raised in Turkey, namely, in the Anatolian Native Black, Eastern Anatolian Red and Turkish Grey. The demonstration of the polymorphisms of these genes would contribute to the improvement of the economic traits affected by these variations.

\section{Materials and Methods}

In this study, blood samples were taken from 139 cattle ( $n=139)$, which were of the Anatolian Native Black $(n=36)$, Eastern Anatolian Red $(n=41)$ and Turkish Grey $(n=52)$ breeds. The blood samples were collected from local cattle breeds, which were raised at national institutes, for the purpose of conservation herds.
This study, which was aimed at the investigation of the calpastatin and thyroglobulin gene polymorphisms in the Anatolian Native Black, Eastern Anatolian Red and Turkish Grey cattle breeds, was performed in several stages, including the isolation of DNA from the blood samples $(0.1 \mathrm{ml})$, the PCR amplification (My Genie 96 Thermal Block Bioner) of the regions investigated in the calpastatin and thyroglobulin genes (the region between exons 5 and 6 in the calpastatin gene (Accession Number: AY008267) (14) and the exon 1 and flanks regions in the thyroglobulin gene (Accession Number: X05380.1) (4) and their cleavage with the restriction endonuclease enzyme (PCR-RFLP), gel imaging with electrophoresis and data assessment by statistical analyses. (DNR Bio-Imaging Systems MiniBIS Pro and software Image Aide from Spectronics Corporation). The obtained data were evaluated by using the GENETIX 4.05 and populations 1.0 statistics programs (6). All procedures were approved by the Ankara University Animal Care and Use Commitee (Meeting date: 13.07.2011, Meeting number: 2011-115, Folder number: 2011-404, Deciscion number: 2011-115-448).

\section{Results}

Agarose gel electrophoresis of calpastatin: The 523 bp region of the calpastatin gene, between exons 5 and 6 , was amplified by PCR. The PCR products were cleaved using the RsaI restriction endonuclease enzyme and separated by $\% 2$ gel electrophoresis, resulting in the observation of 257 and $266 \mathrm{bp}$ fragments under UV light. The image of the band profiles is shown in Figure 1.

Agarose gel electrophoresis of thyroglobulin: The 548 bp region of the thyroglobulin gene of exon 1 and the flanks region (Accession number: X05380.1) was amplified by PCR. The PCR products were cleaved using

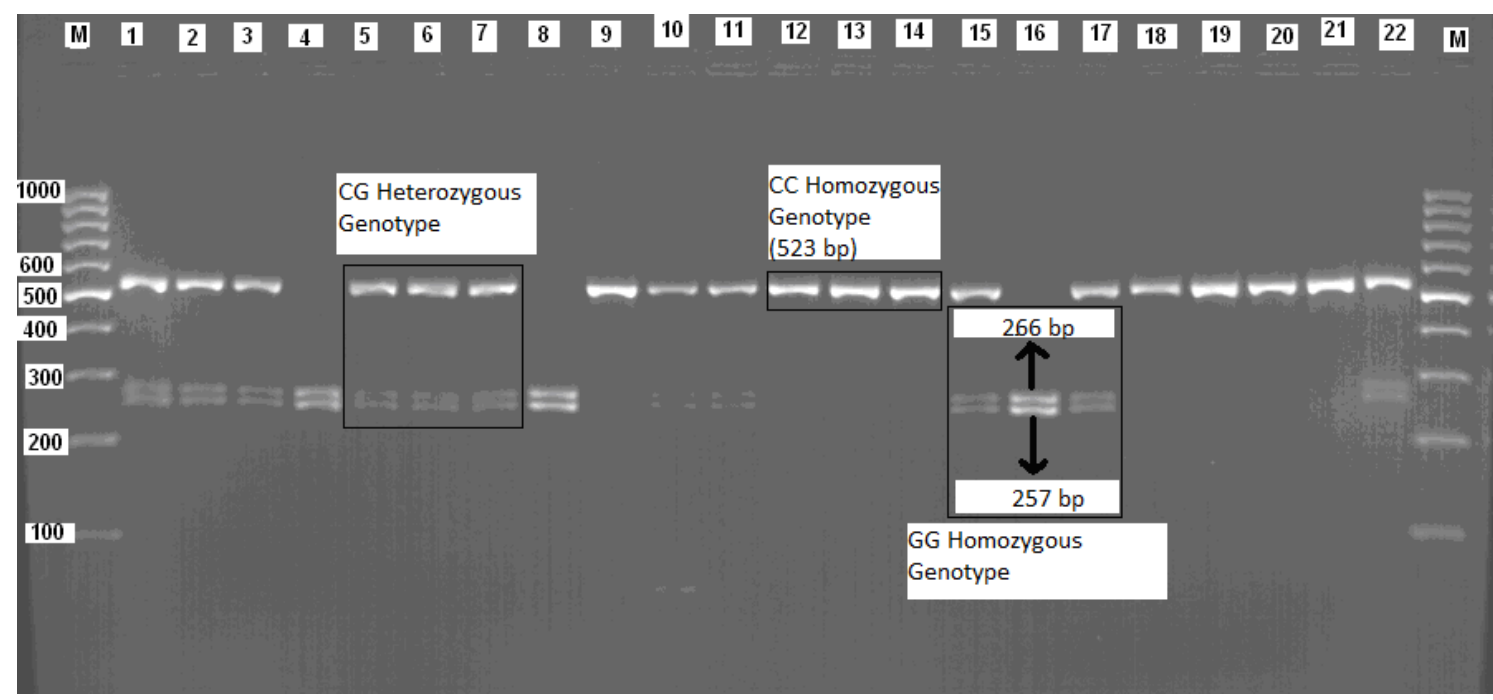

Figure 1. Gel electrophoresis of the calpastatin gene. Şekil 1. Kalpastatin geninin jel elektroforezi. 


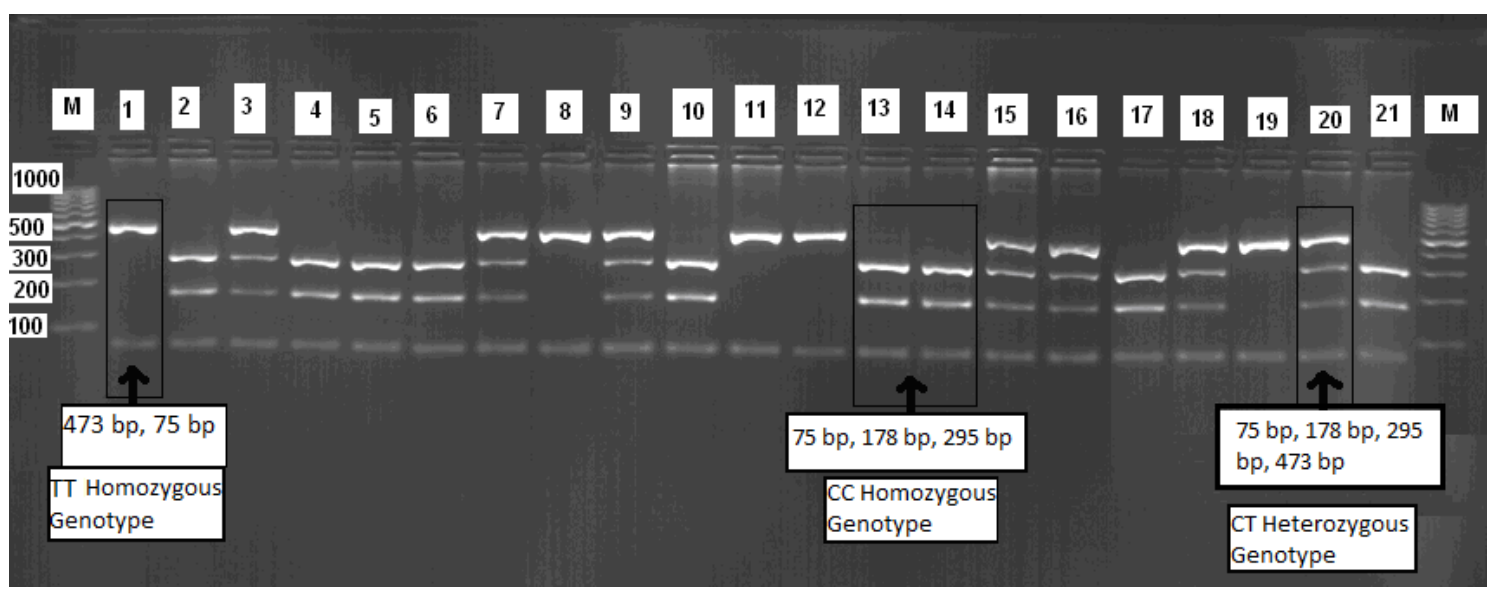

Figure 2. Gel electrophoresis of the thyroglobulin gene.

Şekil 2. Thyroglobulin geninin jel elektroforezi.

Table 1. Genotypic frequencies of the CAST gene.

Tablo 1. CAST geninin genotipik frekans1.

\begin{tabular}{lcccccccc} 
& \multicolumn{2}{c}{ Native Anatolian Black } & \multicolumn{2}{c}{ Eastern Anatolian Red } & \multicolumn{2}{c}{ Turkish Grey } & \multicolumn{2}{c}{ Total } \\
Genotype & $\mathrm{n}$ & Frequency & $\mathrm{N}$ & Frequency & $\mathrm{N}$ & Frequency & $\mathrm{N}$ & Frequency \\
\hline CC & 14 & 0.39 & 22 & 0.43 & 26 & 0.50 & 62 & 0.45 \\
CG & 18 & 0.50 & 24 & 0.48 & 23 & 0.44 & 65 & 0.47 \\
GG & 4 & 0.11 & 5 & 0.09 & 3 & 0.06 & 12 & 0.08 \\
\hline
\end{tabular}

Table 2. Allelic frequencies at the CAST locus in the some native cattle breeds investigated.

Tablo 2. Araştırmada kullanılan bazı yerli sığır ırklarının CAST lokuslarının allel frekansları.

\begin{tabular}{ccccc}
\hline Allel & Native Anatolian Black & Eastern Anatolian Red & Turkish Grey & General Population \\
\hline C & 0.64 & 0.67 & 0.72 & 0.67 \\
G & 0.36 & 0.33 & 0.28 & 0.33 \\
\hline
\end{tabular}

the PsuI restriction endonuclease enzyme and separated by gel electrophoresis, resulting in the observation of 75 , 178, 295 and 473 bp fragments under UV light. The image of the band profiles is shown in Figure 2.

The genotype distribution and allelic frequencies of the calpastatin locus: In the Eastern Anatolian Red, Anatolian Native Black and Turkish Grey cattle, the presence of the genotypes CC, CG and GG was detected at the calpastatin locus. For calpastatin, the $\mathrm{C}$ allele was determined to the greatest frequency in all three of the local cattle breeds investigated.

The calpastatin genotype frequencies were calculated separately for each cattle breed (Table 1). The frequencies of the genotypes $\mathrm{CC}, \mathrm{CG}$ and $\mathrm{GG}$ were determined as $0.45,0.47$ and 0.08 , respectively. In the general population, the differences observed between the genotypic frequencies of the animals were determined to be statistically significant $(\mathrm{P}<0.05)$. The Turkish Grey was the local breed with the greatest frequency of the homozygous $\mathrm{CC}$ allele. The allelic frequencies were calculated according to the Hardy-Weinberg equilibrium, and the differences between the cattle breeds were found to be statistically significant $(\mathrm{p}<0.05)$.

Allelic frequencies were determined in the calpastatin gene for all three cattle breeds. This data is presented in Table 2. In all of the populations, the frequency of the $\mathrm{C}$ allele was greater than the frequency of the $\mathrm{G}$ allele.

The genotype distribution and allelic frequencies of the thyroglobulin locus:The presence of the genotypes CC, CT and TT was determined at the thyroglobulin locus. The thyroglobulin genotypic frequencies were calculated separately for each of the cattle breeds (Table 3). The frequencies of the genotypes CC, CT and TT were determined as $0.64,0.29$ and 0.07 , respectively. In the general population, the differences observed between the genotypic frequencies of the animals were found to be statistically significant $(\mathrm{P}<0.05)$. The Eastern Anatolian Red was the local breed with the greatest frequency of the homozygous TT allele.

Using the same method, the allelic frequencies of the thyroglobulin gene were calculated for all three cattle breeds. This data is presented in Table 4. 
Table 3. Genotypic frequencies of the $T G$ gene.

Tablo 3. $T G$ geninin genotipik frekans1.

\begin{tabular}{ccccccccc}
\hline & \multicolumn{2}{c}{ Anatolian Native Black } & \multicolumn{2}{c}{ Eastern Anatolian Red } & \multicolumn{2}{c}{ Turkish Grey } & \multicolumn{2}{c}{ Total } \\
Genotype & $\mathrm{n}$ & Frequencies & $\mathrm{N}$ & Frequencies & $\mathrm{N}$ & Frequencies & $\mathrm{N}$ & Frequencies \\
\hline CC & 20 & 0.56 & 23 & 0.45 & 46 & 0.88 & 89 & 0.64 \\
CT & 13 & 0.36 & 21 & 0.41 & 6 & 0.12 & 40 & 0.29 \\
TT & 3 & 0.08 & 7 & 0.14 & 0 & 0.0 & 10 & 0.07 \\
\hline
\end{tabular}

Table 4. Allelic frequencies at the $T G$ locus in the some native cattle breeds investigated.

Tablo 4. Araştırmada kullanılan bazı yerli sığır ırklarının $T G$ lokuslarının allel frekansları.

\begin{tabular}{ccccc}
\hline & Anatolian Native Black & Eastern Anatolian Red & Turkish Grey & General Population \\
\hline $\mathrm{C}$ & 0.73 & 0.65 & 0.94 & 0.77 \\
$\mathrm{~T}$ & 0.27 & 0.35 & 0.06 & 0.23 \\
\hline
\end{tabular}

Table 5. The heterozygosity indices (He) and mean heterozygosity values (Ho) at the CAST and TG loci in the local cattle breeds investigated.

Tablo 5. Araştırmada kullanılan yerli ırkların $C A S T$ ve $T G$ lokuslarının heterozigotluk indeksleri (He) ve ortalama heterozigotluk değeri (Ho).

\begin{tabular}{lccccccc}
\hline & \multicolumn{2}{c}{ CAST } & \multicolumn{2}{c}{ TG } & \multicolumn{2}{c}{ Mean } \\
Breed & $\mathrm{N}$ & $\mathrm{He}$ & $\mathrm{Ho}$ & $\mathrm{He}$ & Ho & He & Ho \\
\hline Turkish Grey & 52 & 0.4022 & 0.4423 & 0.1087 & 0.1154 & 0.2555 & 0.2788 \\
Eastern Anatolian Red & 51 & 0.4444 & 0.4706 & 0.4508 & 0.4118 & 0.4476 & 0.4412 \\
Native Anatolian Black & 36 & 0.4614 & 0.5000 & 0.3885 & 0.3611 & 0.4250 & 0.4306 \\
\hline
\end{tabular}

Table 6. $f$ statistical values in the local cattle breeds investigated.

Tablo 6. Araştırmadaki yerli sığır ırklarının $f$ istatistik değerleri.

\begin{tabular}{lllll}
\hline & \multicolumn{1}{c}{ Irk } & $\mathbf{F}_{\text {IS }}$ & $\mathbf{F}_{\text {IT }}$ & $\mathbf{F}_{\text {ST }}$ \\
\hline \multirow{4}{*}{ Calpastatin } & Turkish Grey & -0.057 & -0.067 & -0.009 \\
& Eastern Anatolian Red & -0.081 & -0.075 & 0.004 \\
& Anatolian Native Black & -0.068 & -0.070 & -0.002 \\
& Total & -0.068 & -0.071 & -0.002 \\
& & & 0.001 \\
\multirow{5}{*}{ Thyroglobulin } & Turkish Grey & 0.092 & 0.093 & 0.149 \\
& Eastern Anatolian Red & 0.044 & 0.187 & 0.218 \\
& Anatolian Native Black & 0.067 & 0.270 & 0.130 \\
& Total & 0.082 & 0.200 & 0.055 \\
\hline
\end{tabular}

Table 7. $\mathrm{F}_{\mathrm{ST}} /\left(1-\mathrm{F}_{\mathrm{ST}}\right)$ values (right-angled triangle) and gene flow (D value) (inverse right-angled triangle) between the populations. Tablo 7. Populasyonlar arası $\mathrm{F}_{\mathrm{ST}} /\left(1-\mathrm{F}_{\mathrm{ST}}\right)$ değerler (riht-angled triangle) ve gen akış1 (D value) (inverse right-angled triangle).

\begin{tabular}{lccc}
\hline & Turkish Grey $(\mathrm{n}=52)$ & Eastern Anatolian Red $(\mathrm{n}=51)$ & Anatolian Native Black $(\mathrm{n}=36)$ \\
\hline Turkish Grey & $* * *$ & 0.10410 & 0.06179 \\
Eastern Anatolian Red & 0.09887 & $* * *$ & -0.00408 \\
Anatolian Native Black & 0.05992 & -0.00409 & $* * *$ \\
\hline
\end{tabular}



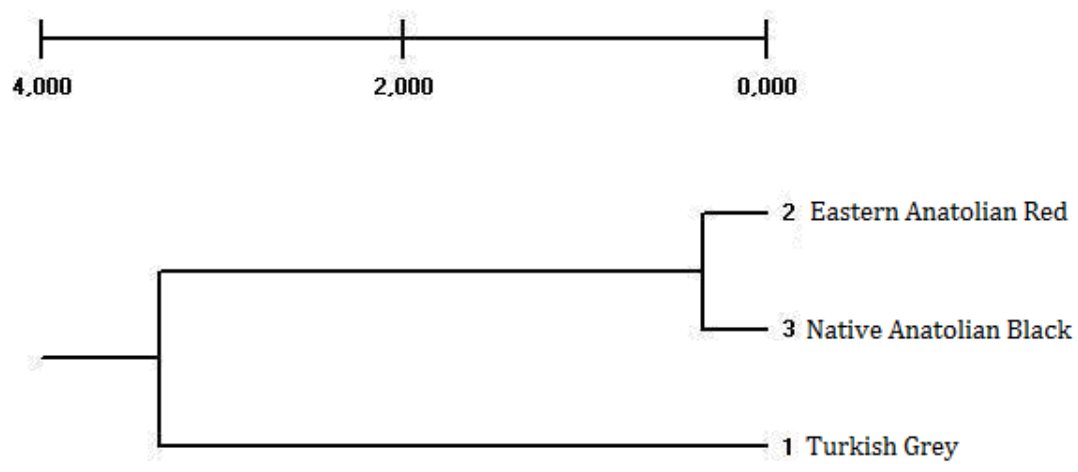

Figure 3. The UPGMA dendrogram showing the relationship between the local cattle breeds investigated. Şekil 3. Araştırmada kullanılan yerli ırklar arasındaki ilişkiyi gösteren UPGMA dendogramı.

\section{Genetic analyses:}

Heterozygosity indices and mean heterozygosity: The most commonly used criterion for the assessment of genetic variation in a population is heterozygosity. The heterozygosity values ( $\mathrm{He}$ and $\mathrm{Ho}$ ) and the mean heterozygosity values determined in the cattle populations investigated in the present study are presented in Table 5. The differences observed between the populations for the mean heterozygosity values were found to be statistically insignificant $(\mathrm{P}>0.05)$.

$f$ statistical values: The population differentiations were tested for each locus and all loci using the $\mathrm{F}_{\mathrm{IT}}(F)$, $\mathrm{F}_{\mathrm{ST}}(\theta)$ and $\mathrm{F}_{\mathrm{IS}}(f)$ fixation indices, and the results obtained are shown in Table 6. Statistically significant differences were determined to exist between the inbreeding coefficients calculated at each locus for the local cattle breeds investigated. The $F_{I S}$ value, the purebreed selection coefficient of the populations analysed, which was also the indicator of the mean heterozygosity deficiency determined for all populations, was determined as $1.03 \%$. The $\mathrm{F}_{\mathrm{IT}}(F)$ value, demonstrating the deviation of the heterozygosity from the HW equilibrium in the general population was calculated as $4.55 \%$. The $\mathrm{F}_{\mathrm{IT}}$ value, demonstrating the inbreeding coefficient and the mean deficiency of heterozygosity in the general population was estimated as $4.55 \%$. The $\mathrm{F}_{\mathrm{ST}}$ value, considered as an indicator of the genetic differentiation between the cattle breeds investigated was calculated as 0.055 .

Genetic distance values, gene flow: Estimations for gene migration, $\left(\log \left(\mathrm{N}_{\mathrm{m}}\right)\right.$ ), and $\mathrm{F}_{\mathrm{ST}}$ statistics (right-angled triangle) between the local cattle breeds investigated are presented in Table 7. As can be seen in the Table 7, the greatest difference between the cattle breeds existed between the Turkish Grey and the Eastern Anatolian Red (0.1041) and the least difference existed between the Anatolian Native Black and the Eastern Anatolian Red (0.00408). On the other hand, it was observed that the gene flow between the Turkish Grey population and the Eastern Anatolian Red population was greater than that between the Turkish Grey population and the Anatolian Native Black population.

The genetic distance values between the local cattle breed populations were calculated as described by Nei (11), and the UPGMA dendrogram (software NTSYS-pc 2.0), which was drawn according to the matrix of these values and demonstrated the correlation between the populations of the different breeds, is presented in Figure 3. As can be seen in the dendrogram, the Eastern Anatolian Red (2) and Anatolian Native Black (3) populations were determined to be similar for the loci investigated. While the Turkish Grey (1) population did not display such similarity, this breed was found to be more similar to the Eastern Anatolian Red compared to the Anatolian Native Black.

The probability values for the chi-square values calculated using the Popgene software 1.31 demonstrated that, at the $\mathrm{P}<0.05$ significance level, only the Anatolian Native Black population was at balance for the calpastatin gene, and this population was not at the Hardy-Weinberg equilibrium for the other breeds and genes. The heterozygosity values of the Anatolian Native Black and Turkish Grey populations were higher than expected.

\section{Discussion and Conclusion}

The present study demonstrated that the RsaI C/G locus in the calpastatin gene had a polymorphic structure in the Anatolian Native Black, Eastern Anatolian Red and Turkish Grey populations. The presence of multiple alleles at this locus suggested a high genetic variation in the population.

The $\mathrm{C}$ allele, which enabled a better tenderness of meat, was found at the highest frequency in the Turkish Grey, followed by the Eastern Anatolian Red and the Anatolian Native Black. While all three of the local cattle breeds investigated in the present study displayed a high potential for meat tenderness, the high consumer preference in Turkey for the meat of the Anatolian Native Black supports the findings of this study. 
The present study demonstrated that the PsuI C/T locus in the thyroglobulin gene was of a polymorphic structure in all three of the local cattle breeds investigated. The polymorphic TG/PsuI structure possessed the $\mathrm{C}$ and $\mathrm{T}$ alleles in all of the breeds. The high frequency of the $\mathrm{T}$ and $\mathrm{C}$ alleles, which enable marbling and meat tenderness, respectively, in the Eastern Anatolian Red supports the high consumer preference for the meat of this particular cattle breed in Turkey.

It was determined that the frequency of the favourable $\mathrm{C}$ allele, which enables the tenderness of meat, was higher than the $\mathrm{G}$ allele.

In a research conducted by Kök et al. (9) to determine the characterization of the calpastatin gene in the Turkish Grey and crosses of the Turkish Grey and the Brown Swiss, the frequency of the $\mathrm{C}$ allele in the Turkish Grey was determined as 0.507 . Therefore, in agreement with the results of the present study, the researchers reported a high frequency of the favourable $\mathrm{C}$ allele.

With respect to the $T G$ gene polymorphism, the genotypes CC, CT and TT were detected in the Eastern Anatolian Red and Anatolian Native Black populations. In the Turkish Grey, only the genotypes CC and CT were detected, and no individual with the genotype TT existed. This suggested that the Eastern Anatolian Red and Anatolian Native Black were more advantageous for marker-assisted selection aimed at the improvement of the marbling score, when compared to the Turkish Grey. However, the presence of individuals with the genotype CT in the Turkish Grey population suggested that this breed also had potential. It is considered that, by means of marker-assisted selection programmes, individuals with the genotype TT would be able to be obtained. The allelic frequencies of the thyroglobulin gene were calculated according to the Hardy-Weinberg equilibrium law. In all three of the local cattle breeds investigated, the $\mathrm{C}$ allele was determined to be of a higher frequency, compared to the $\mathrm{T}$ allele. The possible reasons of the disruption of the Hardy-Weinberg equilibrium were considered to be mutation, selection, the subgrouping of populations, inbreeding within populations and the clustering of certain genotypes in populations $(10 ; 12)$.

The mean heterozygosity value, which is considered as the best estimate of genetic variation in populations and is not affected by the sampling error, was rather high in the Eastern Anatolian Red (0.4412) and the Anatolian Native Black (0.4306), but lower in the Turkish Grey (0.2788).

The mean heterozygosity values being high in the populations investigated was attributed to a low number of polymorphic genetic markers having been studied. Other possible influential factors were the relatively low number of samples tested and the genetic structure of the cattle breeds investigated. Thus, it can be suggested that the rate of homozygosity in the Anatolian Native Black and Eastern Anatolian Red populations was low. The rate of heterozygosity being lower in the Turkish Grey population was attributed to the individuals being close relatives and these animals having been raised in a more closed system.

The underlying reasons of the high heterozygosity rates were thought to be the relative proximity of the local cattle breeds to the evolution site, when compared to the European cattle breeds, and to date, the local cattle breeds of Turkey not having been subjected to selection at the level the highly productive European cattle breeds have been.

The F-statistics used to test any possible deviations from the Hardy-Weinberg equilibrium revealed that, the general $\mathrm{F}_{\mathrm{IS}}(f)$ value of all three local cattle breeds investigated in the present study was -0.01028. The calculation of a negative value demonstrates the deviation of the population from the state of equilibrium and also points out to excessive heterozygosity.

In order to determine the genetic differences between the populations, the $\mathrm{F}_{\mathrm{ST}}$ values were calculated. The $F_{\text {ST }}$ value having been calculated as 0.055 demonstrated that while $5.5 \%$ of the genetic variation originated from differences between the populations, $94.5 \%$ of the genetic variation originated from differences within the populations. The genetic variation within the populations being high suggested that the local cattle breeds had a high genetic variation. Of the population pairs, the Turkish Grey-Eastern Anatolian Red pair presented with the greatest differences (0.1041), while the Anatolian Native Black-Eastern Anatolian Red pair presented with the least differences (0.00408).

Although the local cattle breeds investigated in this study were morphologically rather different from each other, the differences between their $\mathrm{F}_{\mathrm{ST}}$ values were either small or moderate. In other words, the local cattle breeds investigated in the present study were determined to be genetically close to each other.

The $F_{\text {IT }}$ value, indicating the deviation of the heterozygosity of the general population from the HardyWeinberg equilibrium was calculated as $4.55 \%$. This value showed that the homozygosity in the population investigated was $4.5 \%$ higher than expected.

Logarithmically, the greatest gene migration having been determined to have occurred between the Eastern Anatolian Red and Anatolian Native Black populations $(\mathrm{Nm}=3.92)$ suggested that the consanguinity between these two populations was greater than that between the other populations. Furthermore, the gene flow between the Turkish Grey and Eastern Anatolian Red populations was found to be greater than that between the Turkish Grey and Anatolian Native Black populations. Similarly, 
the genetic differentiation of the some native cattle breeds in Turkey is at either a low or moderate level.

Based on all these results, it was ascertained that either a small or moderate genetic differentiation existed between the local cattle breeds raised in Turkey. The investigation of further gene regions and populations would contribute to a more detailed demonstration of genetic differences between the cattle breeds indigenous to Turkey.

In the present study, it was ascertained that the Eastern Anatolian Red and Anatolian Native Black populations were similar in terms of the loci investigated. The Turkish Grey population was less similar, but was closer to the Eastern Anatolian Red than the Anatolian Native Black.

In the present study, the lowest gene flow (D value) was determined between the Anatolian Native Black and the Eastern Anatolian Red (0.00408), and the highest gene flow was determined between the Turkish Grey and the Eastern Anatolian Red (0.10410). In terms of the alleles investigated, it was ascertained that a greater gene flow had occurred from the Turkish Grey to both the Anatolian Native Black and the Eastern Anatolian Red.

A high level of gene migration having been determined between the Eastern Anatolian Red and the Anatolian Native Black populations suggested that the level of consanguinity was greater between these two populations, compared to the others.

The present study is the first research to investigate $T G$ polymorphisms in local cattle breeds raised in Turkey. The results obtained revealed that the local cattle breeds included in the study had the potential for high quality meat production and presented with a high level of genetic variation. Thus, the present study has confirmed the significance of the protection and distribution of local cattle breeds.

\section{References}

1. Anon (2010): NCBI Sequence Viewer 2.8.2. :http: // www. ncbi.nlm. nih. gov/projects/sviewer (14.09.2010).

2. Ailhaud G, Grimaldi P, Negrel, R (1992): Cellular and molecular aspects of adipose tissue development. Cellular and molecular aspects of adipose tissue development. Annual Review of Nutrition, 12, 207-233.

3. Barendse W (2000): Protocol for genotyping TG5 alleles using an MboI restriction endonuclease digest for the GTAC/T single nucleotide polymorphism. CSIRO Molecular Animal Genetics Centre, Gehrmann Laboratories, Research Road, St. Lucia.4072.
4. Barendse W, Bunch R, Thomas M, Armitage S, Baud S, Donaldson N (2004): The TG5 thyroglobulin gene test for a marbling quantitative trait loci evaluated in feedlot cattle. Aust. J. Exp. Agriculture, 44, 669-674.

5. Barendse W, Harrison BE, Hawken RJ, Ferguson DM, Thompson JM, Thomas M, Bunch RJ (2007): Epistasis between Calpain 1 and its inhibitör Calpastatin within breeds of cattle. Genetics. 176, 2601-2610.

6. Belkhir K, Borsa P, Chikhi L, Goudet J, Bonhomme F (1996): Genetix 4.00 Windows $^{T M}$ software for population genetics. Laboratoire Genome. Populations. Interactions. University of Montpellier. Fransa.

7. Georges M, Lequarre AS, Hansel R, Vassart G (1987): Genetic variation of the bovine thyroglobulin gene studied at the DNA level. Animal Genetics. 18 , 41-50.

8. Khatib H, Zaitoun I, Chang YM, Maltecca C, Boettcher P (2007): Evaluation of association between polymorphism within the thyroglobulin gene and milk production traits in dairy cattle. J. Anim. Breed Genet. 124, 26-28.

9. Kök S, Atalay S, Savaşçı M, Eken HS (2013): Characterization of calpastatin gene in purebred and crossbred Turkish Grey steppe cattle. Kafkas Univ. Vet. Fak. Derg. 19, 203-206.

10. Marson PE, Ferraz JBS, Meirelles FV, Eler JP, Figueiredo LG, Mourao GB (2005): Genetic caracterization of Europen-zebu composite bovine using RFLP markers. Genet. Mol. Res. 4, 496-505.

11. Nei M (1972). Genetic distance between populations. Am. Nat. 106: 283-292.

12. Pareek CS, Zieba M, Michno J, Czanik U, Zwierzchowski L (2008): Study of SNP C>T polymorphism within the candidate genes for dairy and beef traits in a panel of selected cattle breeds. J. Agrobiol. 25, 121-124.

13. Rincon G, Medrano JF (2006): Assays for genotyping single nucleotide polymorphismus in the bovine CAPN1 gene. Animal Genetics. 37, 294-295.

14. Schenkel FS, Miller JR, Jiang Z, Mandell IB, Ye X (2006): Association of a single nucleotide polymorphism in the calpastatin gene with carcass and meat quality traits of beef cattle. J. Anim. Sci. 84, 291-299.

15. Zhang HM, Brown DR, Denise SK, Ax RL (1993): Rapid communication: polymerase chain reactionrestriction fragment length polymorphism analysis of the bovine somatotropin gene. J. Anim. Sci. 71, 2276-2279.

Geliş tarihi: 24.10.2014 / Kabul tarihi: 04.03.2015

\author{
Address for correspodence: \\ Dr. Mustafa Savaşçı \\ Ankara University, \\ Graduate School of Healty Sciences, \\ Dışkapı, Ankara, Turkey. \\ e-mail: mustafasavasci2003@gmail.com
}

